\title{
Microscopic alterations in silicone tubes surface after application of ophthalmological lubricants
}

\author{
Alterações microscópicas na superfície de tubos de silicone \\ após aplicação de lubrificantes oftalmológicos
}

Jacqueline Sousa ${ }^{1}$, Mirtha Dittrich¹, Carina Verna ${ }^{1}$, Simone Bison ${ }^{1}$, Paulo Schor $^{1}$

\begin{abstract}
Objective: To identify microscopic morphological alterations in the surface of silicone tubes used for intubation of the lachrymal system after exposure to ophthalmological lubricants. Methods: Experimental, descriptive and longitudinal study consisted of the application of ophthalmological lubricants in silicone tubes. The tubes were divided in: Group 1 (Cylocort $\left.{ }^{\circledR}\right), 2$ (Epitezan $\left.{ }^{\circledR}\right), 3$ (Labcaina $\left.{ }^{\circledR}\right), 4$ (Liposic $\left.{ }^{\circledast}\right)$, $5\left(\right.$ Maxinom $\left.^{\circledR}\right)$ and $6\left(\right.$ Vista Gel $\left.^{\circledR}\right)$. One tube was not exposed to any lubricant, used as control. The tubes were observed and photographed after 2 hours, 30 days, 45 days before and after cleaning the surface and lumen. The following aspects were observed: surface (regularity, transparency, quantity,size and shape of the substances) and lumen (obstruction). Results: Control: irregular surface with pores after 2 hours: Group 1 -irregular surface with presence of film; Groups 2, 3 and 5 -abundant and irregular quantity of ointment at the surface; Group 4 - discrete modification at the surface; Group 6 - growth of pigmented (brownish) structures with filaments in the lumen, with discrete film in the surface. 30 Days: Groups 1, 4 and 5 - increase of the irregular superficial film; Group 2 - crust with notorious horizontal lines; Group 3 - diminution of the superficial film; Group 4 - crust less evident. Group 6-increase of the structure seen with 2 hours of exposition, arboriform aspect. Forty-five days pre cleaning: Group 4 - diminution of the surface crust; Group 6 expansion of the arboriform structure; unaltered findings in other groups. 45 days after cleaning: Groups 1 and 5 - light diminution of the surface crust; Groups 2, 3 and 4 - kept the modifications; Group 6 - the structure inside the lumen was not identified, clear surface, without evidence of film. Conclusion: Microscopic morphological alterations in the surface and lumen of silicone tubes can occur when those remain in contact with determined ophthalmological lubricants.
\end{abstract}

Keywords: Silicone tubes; Microscopic alterations; Ophthalmological lubricants

\section{RESUMO}

Objetivo: Identificar alterações morfológicas na superfície de tubos de silicone usados para intubação do sistema lacrimal após exposição a lubrificantes oftalmológicos. Métodos: Estudo experimental, descritivo e longitudinal que consistiu na aplicação de lubrificantes oftalmológicos em tubos de silicone. Os tubos foram divididos em: Grupo 1 (Cylocort $\left.{ }^{\circledR}\right), 2$ (Epitezan $\left.{ }^{\circledR}\right), 3$ (Labcaína ${ }^{\circledR}$ ), 4 $\left(\right.$ Liposic $\left.^{\oplus}\right), 5$ (Maxinom $\left.^{\oplus}\right)$ e $6\left(\right.$ Vista Gel $\left.^{\circledR}\right)$. Um tubo não foi exposto a nenhum lubrificante, sendo usado como controle. Os tubos foram observados e fotografados após 2 horas, 30 dias, 45 dias antes e após limpeza da sua superfície e lúmen. Os seguintes aspectos foram observados: superfície (regularidade, transparência, quantidade, tamanho e formato das substâncias) e lúmen (obstrução). Resultados: Controle - superfície irregular com poros. Após 2 horas: Grupo 1 - superfície irregular com presença de filme; Grupos 2,3 e 5 - quantidade abundante e irregular de pomada na superfície; Grupo 4 - discreta modificação da superfície; Grupo 6 crescimento de estrutura pigmentada (marrom) com filamentos no lúmen, com discreto filme na superfície. Trinta dias: Grupos 1, $4 \mathrm{e}$ 5 - aumento do filme irregular na superfície; Grupo 2 - crosta com linhas horizontais; Grupo 3 - diminuição do filme superficial; Grupo 4 - crosta menos evidente; Grupo 6 - aumento da estrutura vista com 2 horas de exposição, aspect arboriforme. Quarenta e cinco pré-limpeza: Grupo 4 - diminuição da crosta superficial; Grupo 6 - aumento da estrutura arboriforme; os demais grupos sem alterações. Quarenta e cinco dias pós-limpeza: Grupo 1 e 5 - discreta diminuição da crosta superficial; Grupos 2, 3 e 4 - modificações mantidas; Grupo 6 - a estrutura dentro do lúmen não foi visualizada, superfície limpa sem evidência de filme. Conclusão: As modificações na morfologia microscópica na superfície e lúmen de tubos de silicone podem ocorrer após contato com determinados lubrificantes oftalmológicos.

Descritores: Tubos de silicone; Alterações microscópicas; Lubrificantes

\footnotetext{
'Oculoplastic Surgery Service and Ocular Bioengineering, Department of Ophthalmology and Visual Sciences - (Unifesp) Universidade Federal de São Paulo (SP), Brazil
}

The authors declare no conflicts of interest 


\section{INTRODUCTION}

I ntubation of the lacrimal drainage system is an established procedure for the treatment of congenital obstructions and also to maintain the surgical ostium after dacryocystorhinostomy. Silicone is the standard material for intubation. Based on empirical individual experiences, most ophthalmologists agree that the lubrication of silicone tube during intubation of the lacrimal system is important to avoid mechanical change in the structure of the lacrimal drainage system. The lubricant chosen must be harmless to the patient and the chemical nature of the probe. There are reports describing interaction between polymers used in medical devices and chemicals causing modification of the structure and tension of the material ${ }^{(1,2)}$. However, there are no studies in the literature showing the appearance of the silicone surface after exposure to ocular formulations.

This study aims to identify microscopic morphological changes resulting from the application of eye lubricants on the surface of silicone tubes used for intubation of the lacrimal system.

\section{Methods}

Experimental, longitudinal and descriptive study consisted of application of ophthalmic lubricants in silicone tubes used clinically for intubation of the lacrimal system. The tubes were from the same batch and all the materials were within the expiry date and on storage conditions recommended by the manufacturers.

Silicone tubes measured $5 \mathrm{~cm}$ in length, the area observed was standard with length of $10 \mathrm{~mm}$. The characteristics of the tube were: $0.8 \mathrm{~mm}$ external diameter and $0.3 \mathrm{~mm}$ internal diameter. Each tube was placed on a slide for microscopy and applied lubricant. Nineteen tubes were tested in total and divided into seven groups; six groups of three tubes each exposed to six different materials: group 1 (Cylocort ${ }^{\circledR}$ ointment), group 2 (Epitezan ${ }^{\circledast}$ ointment), group 3 (Labcaína ${ }^{\circledR}$ jelly), group 4 (Liposic ${ }^{\circledR}$ gel), Group 5 (Maxinom ${ }^{\circledR}$ ointment) and group 6 (Vista Gel ${ }^{\circledR}$ gel) (table 1). The remaining tube was not exposed to any lubricant, used as the control.

After application of the substances, the silicone tubes remained at room temperature without exposition to sunlight. The tubes were observed and photographed with a 4 times increase with the light microscope. The digital images were taken by a computerized system, constituted by light microscope (Carl Zeiss, Germany) adapted to a high-resolution camera (AxioCam

Table 1

\section{Lubricants used in each group}

\begin{tabular}{llll}
\hline Group & Tradename & Laboratory & Presentation \\
\hline 1 & Cylocort $^{\circledR}$ & Genom & Ointment \\
2 & Epitezan $^{\circledR}$ & Allergan & Ointment \\
3 & Labcaína $^{\circledR}$ & Pharlab & Jelly \\
4 & Liposic $^{\circledR}$ & Bausch + Lomb & Gel \\
5 & Maxinom $^{\circledR}$ & Genom & Ointment \\
6 & Vista Gel $^{\circledast}$ & Croma Pharma & Visco-elastic solution \\
\hline
\end{tabular}

MRC, Carl Zeiss, Germany) and colorful computer monitor (Samsung). The images were processed and analyzed by the program AxioVision version 4.3 (Carl Zeiss, Germany). The images were taken after a period of 2 hours of exposition, 30 days of exposition, 45 days of exposition before and after cleaning the surface and lumen of the tubes with filtered flow water. For each tube, the following aspects were observed: surface (regularity, transparency, quantity, form and shape of the substances) and lumen (obstruction). The results were consequence of visual comparison of the photographic documentation.

\section{Results}

The control tube presented with slightly irregular surface with small pores, transparent and free lumen throughout the period of experimentation (figure 1).

After 2 hours of exposure, the group 1 (Cylocort ${ }^{\circledR}$ ) showed slightly irregular due to the presence of the ointment surface, forming a film with little change in transparency, allowing view the totally free lumen. Groups 2 (Epitezan $\left.{ }^{\circledR}\right), 3$ ( Labcaína $^{\circledR}$ )

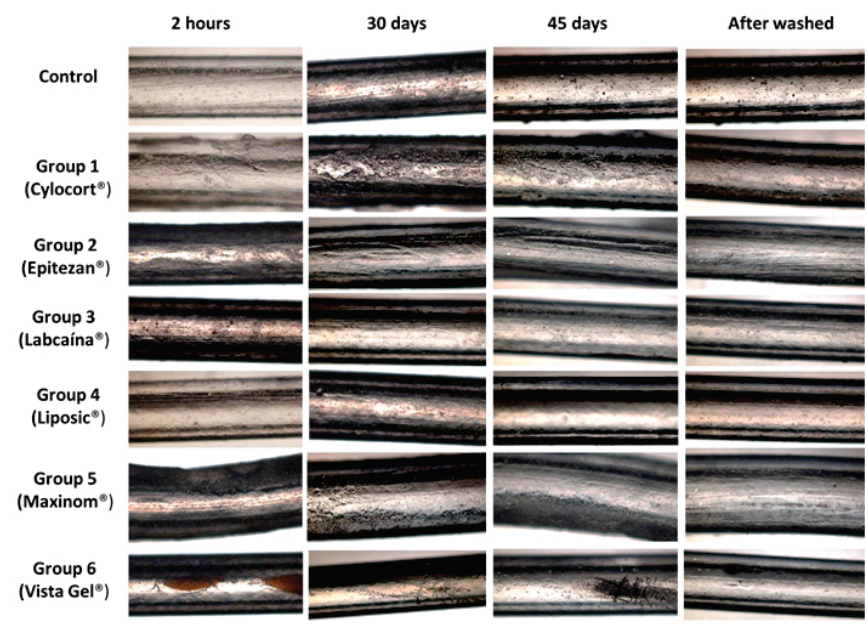

Figure 1: Photographic images of the silicone tubes in 2 hours, 30 days and 45 days (pre and post cleaning): Control: irregular surface with pores and free lumen during all the period of experimentation; After 2 hours: Group 1 - irregular surface with presence of film, little alteration of the transparency and free lumen free; Groups 2, 3 and 5 - similar characteristics with group 1 , but with abundant and irregular quantity of ointment at the surface, and moderated difficulty for viewing the lumen; Group 4 - discrete modifications at the surface when compared with the group control; Group 6 - presence of pigmented (brownish) structures with filaments in the lumen, with discrete film in the surface; 30 Days: Groups 1, 4 and 5 -increase of size of the superficial film verified with 2 hours of exposition, irregular crust and difficulty of observing the lumen; Group 2 - crust formation with notorious horizontal lines, without alterations in the lumen; Group 3-diminution of the superficial film, similar to control tube; Group 4 - crust less evident; Group 6 - increase of size of the structure seen with 2 hours of exposition, arboriform aspect; 45 days pre cleaning: Group 4 - diminution of the surface crust with free lumen free; Group 6 - expansion of the arboriform structure; the other groups presented unaltered findings. 45 days after cleaning: Groups 1 and 5 - light diminution of the surface crust, without alterations in the lumen; Groups 2, 3 and 4 - kept the modifications in the surface and lumen; Group 6 - the structure inside the lumen was not identified, clear surface, without evidence of film 


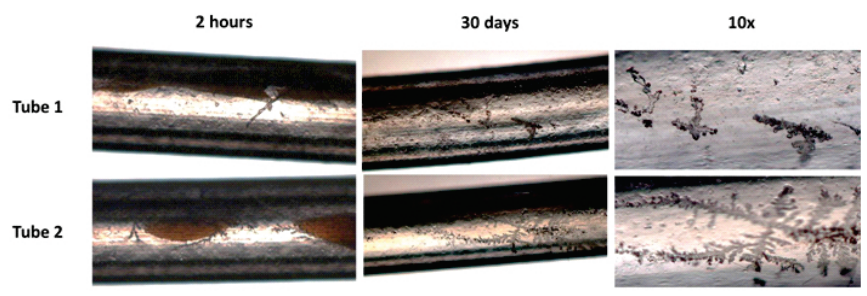

Figure 2: Photomicrograph demonstrating the leaf fern aspect seen in the lumen of the group 6 tubes (Vista Gel®)

and 5 (Maximon $\left.{ }^{\circledR}\right)$ exhibited similar characteristics, uneven surface, abundant ointment caused moderately difficult to distinguish the lumen. The group 4 (Liposic ${ }^{\circledR}$ ) showed only slight change in the surface when compared with the control group. In group $6\left(\right.$ Vista $\left.\mathrm{Gel}^{\circledR}\right)$ there was grew of a pigmented filamentary structure at the lumen of the 3 tubes exposed to this substance, with a slight film on the surface (figure 2)

With 30 days of exposure, groups 1 (Cylocort $\left.^{\circledR}\right), 4$ $\left(\right.$ Liposic $^{\circledR}$ ) and 5 (Maxinom ${ }^{\circledR}$ ) showed an increased size of the surface film observed with 2 hours of exposure, causing an uneven crust on the surface of the tubes, making it hard to observe the lumen. For group 4 (Liposic $\left.{ }^{\circledR}\right)$, the crust was less obvious. In group 2 Epitezan $\left.^{\circledR}\right)$ there was a crust formation with noticeable horizontal lines, without changes in the lumen. In group 3 (Labcaína ${ }^{\circledR}$ ) we observed a decrease in the surface film, with similar appearance to the control tube. In group 6 (Vista Gel ${ }^{\circledR}$ ), there was an increase of the filamentary structure seen with 2 hours of exposure, with arboriform aspect.

Following 45 days of exposure, the only groups that showed changes were groups 4 and 6 . Group 4 (Liposic ${ }^{\circledR}$ ) had a significant decrease in the crust on the surface of the tubes, making possible to see a free lumen. Group 6 (Vista $\mathrm{Gel}^{\circledR}$ ) continued with the growth of the arboriform structure within the lumen in the 3 tubes, with an increase of size and pigmentation.

After washing the silicone tubes with filtered flow water at the 45th day of exposure, groups 2 (Epitezan $\left.{ }^{\circledR}\right), 3$ (Labcaína ${ }^{\circledR}$ ) and 4 (Liposic $\left.{ }^{\circledR}\right)$ did not showed alterations on the surface and lumen of theirs tubes. Groups 1 (Cylocort ${ }^{\circledR}$ ) and 5 (Maximon ${ }^{\circledR}$ ) had a slight decrease of the crust on the surface, without changes in the lumen. In group 6 (Vista $\mathrm{Gel}^{\circledR}$ ) we could not identify the intra-luminal contents previously observed in the 3 tubes, the surface became transparent without evidence of film.

\section{Discussion}

The breakage or slippages of the silicone tube are complications that may be related to the damage to its surface. One of the possible causes of changes on the silicone tube can be the use of lubricants during the surgical procedure. Ophthalmic ointments can be hydrophobic with a high fat content (ointments in fact) or hydrophilic (gel). Among hydrophobic compounds, it is known that Vaseline can affect the integrity of the materials made of latex (gloves, catheters, probes) ${ }^{(1-3)}$

There are no studies in the scientific literature about possible harmful effects of lubricants in silicone materials used in Medicine, nor even about its influence in the surface of silicone tubes. The objective of this study was to identify microscopic morphological alterations in the surface of silicone tubes used for intubation of the lachrymal system after exposure to ophthalmological lubricants. The lubricants with presentation ointment (groups 1 - Cylocort $^{\circledR}, 2$ - Epitezan ${ }^{\circledR}$ and 5 - Maxinom ${ }^{\circledR}$ ) showed up the biggest modifications in the surface, with irregular crusts that did not changed after washing with flow water. The groups 3 (Labcaína $\left.{ }^{\circledR}\right), 4$ (Liposic $^{\circledR}$ ) and 6 (Vista $\mathrm{Gel}^{\circledR}$ ), with presentation of jelly, gel and visco-elastic solution respectively, presented little modification of the silicone tubes surfaces when comparing to the control tube.

Group 6 (Vista $\mathrm{Gel}^{\circledR}$ ) was the only group that presented a progressive growth of a fern pattern structure in the lumen of the tubes. This structure disappeared after cleaning with filtered flow water. Possibly, this appearance was caused by crystallization of the material. Londa described as characteristics of cellulose polymers the porosity and crystallization ${ }^{(4,5)}$. After cleaning the tubes, the lumen was completely free, which would not occur with biofilms. Knowing that the tubes were not from patients, the tubes were not submitted to culture.

Parsa et al. ${ }^{(6)}$ demonstrated that biofilm may occur in Crawford probe with micro and macro bacterial colonies of different morphologies (rods, spirochetes, fusiform and coconuts) in all its internal and external surface. This must be remembered as a cause of change in the structure of the silicon tubes. Biofilms can also cause persistent and difficult to control infection. Others silicone materials used in ophthalmological routine can develop biofilm with serious infection, as the silicone band for retinopexy, lachrymal plug, intraocular lens and contact lens ${ }^{(7,9)}$.

The limitation of this study is in the fact that it researched only the morphological aspect of the silicone tubes in laboratory. For recommendations in vivo will be necessary more comparative clinical studies.

\section{Conclusion}

This study determined that morphological changes in the microscopic appearance of the surface and lumen of silicone tubes can occur when these remain in contact with certain ophthalmic lubricants. More studies are needed to assess whether this change also extends to the physical chemistry structure of the silicone tube during intubation of the lacrimal system. Also, if there are changes in its resistance and increasing the risk of rupture in the postoperative period and/or facilitating the biofilm formation on its surface.

\section{RefERENCES}

1. Curtis J,Klykken P.A Comparative assessment of three common catheter materials [Internet]. Dow Corning Corporation. Available: http:// www.dowcorning.com/content/publishedlit/52-1116.pdf

2. Department of Health, National Agency of Sanitary Vigilance (ANVISA). The first world challenge for security of the patient. Informative sheet 6: I use of Gloves (technical). Brasilia: Department of the Health, 2014. Available: www.who.int/gpsc/en/index.html

3. Gaspar-Sobrinho FP, Esperidão AC, Lessa HÁ. Effect of lubricants on the integrity of the Foley cateter and their implications in nasal packing for epistaxis. Rev Bras Otorrinolaringol. 2004;70(3):295-9.

4. Londa M. Compressed of liberation prolonged. It influences of polymers celulósicos in the modelação of the cedência of fármacos little soluble. Theory of Doctorate, Coimbra: Faculty of Pharmacy, University of Coimbra; 2006. 
5. Curtis J, Colas A. Medical applications of silicones. In: Ratner BD, editor. Biomaterials science: An introduction to materials in Medicine. 2nd ed. New York: Elsevier Academic Press; 2004. p. 697-707.

6. Parsa K, Schaudinn C, Gorur A, Sedghizadeh PP, Johnson T, Tse DT, Costerton JW. Demonstration of bacterial biofilms in culture-negative silicone stent and Jones tube. Ophthal Plast Reconstr Surg. 2010;26(6):426-30.

7. Holland SP,Pulido JS, Miller D, Ellis B, Alfonso E, Scott M, et al. Biofilm and scleral buckle-associated infections. A mechanism for persistence. Ophthalmology. 1991; 98(6):933-8.

8. Sugita J, Yokoi N, Fullwood NJ, Quantock AJ, Takada Y, Nakamura Y,et al. The detection of bacteria and bacterial biofilms in punctual plug holes. Cornea. 2001;20(4):362-5.
9. Stapleton F, Dart J. Pseudomonas Keratitis associated with biofilm formation on a disposable soft contact lens. Br J Ophthalmol. 1995; 79(9):864-5

\section{Corresponding author:}

Mirtha Dittrich

R. Botucatu, $n^{\circ} 821$ - Vila Clementino

Zip code: 04023-062 - São Paulo (SP), Brazil

Phone: 55 (11) 5085-2010

E-mail: mar.dittrich@hotmail.com 